\title{
DESKRIPSI MODEL PEMBELAJARAN PROBING PROMPTING UNTUK MENINGKATKAN KEMAMPUAN BERPIKIR KRITIS MATEMATIKA PESERTA DIDIK KELAS VIII SMPN 04 KOTA BENGKULU
}

\author{
${ }^{1}$ Nurmadhani Febrianti, ${ }^{2}$ Agus Susanta, ${ }^{3}$ Della Maulidiya \\ ${ }^{123}$ Program Studi Pendidikan Matematika FKIP, Universitas Bengkulu \\ email : ${ }^{1}$ nurmadhani.febrianti@gmail.com, ${ }^{2}$ unibagus@yahoo.com, ${ }^{3}$ della.maulidiya@unib.ac.id
}

\begin{abstract}
Abstrak
Penelitian ini bertujuan untuk mengetahui cara menerapkan model pembelajaran probing prompting agar terjadi peningkatan kemampuan berpikir kritis matematika peserta didik kelas VIII SMP Negeri 04 Kota Bengkulu. Jenis penelitian yang dilaksanakan adalah Penelitian Tindakan Kelas (PTK) dengan teknik pengumpulan data melalui tes hasil belajar dan Lembar Kerja Peserta Didik (LKPD). Subjek dalam penelitian ini adalah peserta didik kelas VIII.1 SMP Negeri 04 Kota Bengkulu tahun ajaran 2017/2018. Hasil penelitian ini menunjukkan penerapan model pembelajaran probing prompting dapat meningkatkan kemampuan berpikir kritis matematika peserta didik. Peningkatan kemampuan berpikir kritis matematika dari siklus I hingga siklus III yaitu berturut-turut, 54\% kategori sedang; 79\% kategori tinggi; dan 87\% kategori sangat tinggi. peningkatan kemampuan berpikir kritis dapat dilakukan dengan cara memberikan bimbingan untuk menyelesaikan LKPD sesuai dengan indikator berpikir kritis, memberikan pertanyaan probing prompting dengan tingkat kognitif penerapan, menggunakan alat peraga.
\end{abstract}

Kata kunci : Model Pembelajaran Probing Prompting, Kemampuan berpikir kritis matematika

\begin{abstract}
This study aims to determine how to implement the model probing prompting learning in order to critical thinking skills of mathematics students class VIII. 1 SMP N 04 City of Bengkulu. This type of research carried out is a Class Action Research (PTK) with data collection through achievement test and Worksheet Students (LKPD). Subjects in this study was the students of class VIII 1 SMP N 04 City of Bengkulu 2017/2018 academic year. The results of this study indicate probing prompting learning model application can improve critical thinking skills of mathematics learners. Increase critical thinking skills of mathematics from the first cycle to the third cycle, 54\% moderate category; $79 \%$ of high category; and $87 \%$ very high category. increase in critical thinking skills can be done by providing guidance to resolve LKPD according to indicators of critical thinking, providing probing questions prompting the cognitive level of the application, using props.
\end{abstract}

Keywords : Probing Prompting Learning Model, critical thinking skills of mathematics

PENDAHULUAN

Schoenfeld (dalam Hendriana dan

Soemarno, 2014: 3) menyimpulkan

"matematika sebagai ilmu tentang pola perlu dikembangkan lebih lanjut". Matematika memuat pengamatan dan pengkodean melalui representasi yang abstrak, dan peraturan dalam dunia simbol dan objek. Matematika sebagai 
suatu disiplin ilmu yang secara jelas mengandalkan proses berpikir yang dipandang sangat baik untuk diajarkan pada peserta didik. Matematika adalah bahasa yang melambangkan serangkaian makna dari pernyataan yang ingin kita sampaikan. Soemarmo (2014 :2) menyimpulkan seperti dalam bahasa lainnya, dalam matematika terdapat pula sejumlah simbol yang diadopsi dari bahasa lainnya misalnya dalam aljabar digunakan huruf latin. Matematika merupakan salah satu mata pelajaran yang masih dianggap sulit dipahami oleh peserta didik. Kesulitan belajar itu disebabkan karena sifat dari matematika yang memiliki objek abstrak. Terkait terhadap anggapan berlebihan mengenai matematika, ditemukan beberapa penyebab fobia matematika antara lain adalah mencakup penekanan berlebihan pada penghapalan semata, penekanan pada kecepatan berhitung, pengajaran otoriter, serta kurangnya variasi dalam proses belajar mengajar matematika.

Berdasarkan hasil wawancara peneliti dengan guru matematika yang mengajar kelas VIII pada Senin 08 Januari 2018 di SMP Negeri 04 Kota Bengkulu bahwa kemampuan berpikir dalam pembelajaran matematika peserta didik masih tergolong rendah. Khususnya kemampuan berpikir kritis peserta didik dalam materi bangun ruang sisi datar. Hendaknya pada materi ini yang dominan mengandalkan kemampuan daya pikir, peserta didik diharapkan mampu mengatasi permasalahan pembelajaran matematika yang materinya cenderung bersifat abstrak, dengan begitu peserta didik akan lancar mengerjakan soal - soal yang diberikan.

Pembelajaran Matematika hendaknya disampikan dengan menggunakan suatu metode atau model mengajar yang bervariasi, sehingga peserta didik tidak bosan atau jenuh saat belajar. Salah satu model pembelajaran yang dapat digunakan adalah probing-prompting, Penggunaan model pembelajaran probingprompting dapat membangkitkan kemampuan berpikir peserta didik, sehingga ketika pembelajaran berlangsung peserta didik harus memperhatikan dengan baik agar dapat memahami pelajaran yang disampaikan oleh guru. Artinya dalam penggunaan metode atau model mengajar tidak harus sama untuk semua pokok bahasan.

Model pembelajaran probing-prompting sangat cocok diterapkan pada pembelajaran matematika karena dalam mempelajari matematika tidak cukup hanya mengetahui dan menghafal konsep-konsep matematika tetapi juga dibutuhkan suatu kemampuan peserta didik untuk berpikir kritis menyelesaikan persoalan matematika dengan baik dan benar.

Berdasarkan uraian sebelumnya maka perumusan masalah dalam penelitian ini :

Apakah kemampuan berpikir kritis matematika dapat ditingkatkan dengan metode pembelajaran probing prompting ?

Tujuan dari penelitian ini adalah untuk mengetahui kemampuan berpikir kritis matematika yang diajarkan dengan menggunakan model pembelajaran probing prompting.

\section{Kemampuan Berpikir Kritis Matematika}

Kemampuan berpikir kritis menurut Glaser (dalam Fisher, 2009: 3) adalah "berpikir kritis sebagai suatu sikap mau berpikir secara mendalam tentang masalah-masalah dan halhal yang berada dalam jangkauan pengalaman seseorang, pengetahuan tentang metode-metode pemeriksaan dan penalaran yang logis, dan semacam suatu keterampilan untuk menerapkan metode-metode tersebut". Ennis dalam Soemarmo (2017: 41) menyimpulkan "berpikir kritis sebagai berpikir reflektif yang beralasan dan difokuskan pada penetapan apa yang dipercayai atau yang dilakukan".

Soal-soal berpikir kritis dalam matematika harus memuat :

1. Situasi yang tidak familiar dimana individu tidak dapat dengan cepat memahami konsep matematika atau mengetahui bagaimana menentukan solusi dari persoalan.

2. Menggunakan pengetahuan awal, penaran matematika, dan strategi kognitif.

3. Generalisasi, pembuktian, dan atau evaluasi.

Nurmadhani, Agus, Della 
4. Berpikir reflektif yang melibatkan pengkomunikasian solusi dengan penuh pertimbangan, membuat makna tentang jawaban atau argument yang masuk akal, menentukan alternatif untuk menjelaskan konsep.

Indikator kemampuan berpikir kritis yang dinilai ada 4 indikator yaitu menggeneralisasi dan mempertimbangkan hasil generalisasi, mengidentifikasi relevansi, merumuskan masalah ke dalam model matematika dan mendeduksi dengan menggunakan prinsip.

\section{METODE}

Jenis penelitian yang dilakukan adalah Peneltian Deskriptif. Sugiyono (2005: 21) menyatakan bahwa metode deskriptif adalah suatu metode yang digunakan untuk membuat kesimpulan yang lebih luas. Dapat dikatakan bahwa penelitian deskriptif merupakan penelitian yang berusaha mendeskripsikan suatu gejala, peristiwa yang terjadi pada saat sekarang atau masalah actual.

\section{Tempat dan Waktu Penelitian}

Penelitian ini dilaksanakan di SMP Negeri 04 Kota Bengkulu dan waktu penelitiannya pada bulan Maret-Mei tahun 2018 semester genap tahun ajaran 2017/2018.

\section{Subjek Penelitian}

Populasi penelitian ini yaitu seluruh kelas VIII SMP Negeri 04 Kota Bengkulu, sedangkan sampel penelitiannya adalah kelas VIII 1, alasannya karena varians nilai pada kelas VIII 1 besar. Pemilihan kelas dilakukan dengan metode purposif yaitu pemilihan berdasarkan pertimbangan-pertimbangan seperti memiliki rata-rata rendah dan varians yang terbesar. Sampel penelitian ini diperoleh dari nilai rata-rata ujian akhir semester ganjil kelas VIII.1 SMPN 04 Kota Bengkulu tahun ajaran 2017/2018 yang menunjukkan bahwa nilai rata-rata ujian akhir semester ganjil kelas VIII.1 masih di bawah KKM yang ditetapkan sekolah yaitu 75 .

\section{Prosedur Penelitian}

Penelitian yang dilakukan adalah penelitian deskriptif, yang dilakukan sebanyak 12 pertemuan. Penelitian ini mendeskripsikan model probing prompting untuk meningkatkan kemampuan berpikir kritis matematika. Berikut uraian model pembelajaran probing prompting untuk meningkatkan kemampuan berpikir kritis setiap pertemuan :

1. Pembelajaran setiap pertemuannya dimulai dengan pemberian pertanyaan awal dan perumusan jawaban oleh peserta didik.

2. Pemberian pertanyaan probing prompting dilakukan setelah pertanyaan aawal. Pertanyaan probing diberikan setelah peserta didik dapat menjawab pertanyaan awal dengan benar, sedangkan pertanyaan prompting siberikan jika jawaban peserta didik masih salah.

3. Pengerjaan LKPD oleh peserta didik

Tahap-tahap tersebut selalu disesuaikan dengan indikator kemampuan berpikir kritis, yang diantaranya indikator menggeneralisasi dan mempertimbangkan hasil generalisasi, mengidentifikasi relevansi, merumuskan masalah ke dalam model matematika dan mendeduksi dengan menggunakan prinsip.

\section{Instrumen Penelitian}

1. Lembar tes hasil belajar

Arikunto (2014: 193) menyatakan bahwa "tes adalah serentetan pertanyaan atau latihan serta alat lain yang digunakan untuk mengukur keterampilan, pengetahuan intelegensi, kemampuan atau bakat yang dimiliki oleh individu atau kelompok". Arifin (2012: 118) menyimpulkan tes adalah suatu tekhnik atau cara yang digunakan dalam rangka melaksanakan kegiatan pengukuran, yang didalamnya terdapat berbagai pertanyaan, pernyataan, atau serangkaian tugas yang harus dikerjakan atau dijawab oleh peserta didik untuk mengukur aspek perilaku peserta didik. Tes yang dilakukan adalah tes akhir siklus berupa tes tertulis. Tes ini dilakukan untuk mengetahui kemampuan berpikir kritis matematika peserta didik yang disusun berdasarkan tujuan pembelajaran khusus setiap akhir siklus. Hasil dari tes ini digunakan sebagai acuan untuk tindakan selanjutnya.

2. Lembar Kerja Peserta Didik (LKPD)

Nurmadhani, Agus, Della

Deskripsi Model Pembelajaran Probing Prompting Untuk Meningkatkan Kemampuan Berpikir Kritis Matematika Peserta Didik Kelas VIII SMPN 04 Kota Bengkulu 
LKPD dirancang, disusun, dan dikembangkan untuk keperluan penelitian disesuaikan dengan indikator variable yang diteliti dan tujuan pembelajaran pada pokok bahasan yang diamati. Pengerjaan LKPD akan dilakukan secara berkelompok.

\section{Teknik Pengumpulan Data}

1. Tes Hasil Belajar Peserta didik

Data hasil belajar peserta didik diperoleh dari tes yang dilakukan setelah pembelajaran menggunakan model probing-prompting dengan indikator berpikir kritis matematika berlangsung. Tes ini bertujuan untuk melihat kemampuan peserta didik dari siklus pertama sampai siklus akhir.

2. Lembar Kerja Peserta Didik (LKPD)

Lembar kerja Peserta Didik dberikan kepada peserta didik ketika proses pembelajaran berlangsung. LKPD dikerjakan secara berkelompok, yang berisikan beberapa soal terkait model probing-prompting dan kemampuan berpikir kritis matematika.

\section{Teknik Analisa Data}

\section{Analisis Lembar Tes Kemampuan Berpikir Kritis Matematika Peserta didik}

Peneliti menganalisis hasil tes siklus secara kuantitatif untuk mengetahui kemampuan berpikir kritis matematika peserta didik. Persentase pencapaian indikator kemampuan berpikir kritis matematika dihitung menggunakan persamaan :

$$
\mathrm{K}=\frac{\sum \text { Skor perolehan }}{\sum \text { Skor Maksimal }} \times 100 \%
$$

Modifikasi : Aqib, dkk (2014: 41)

Keterangan:

$\mathrm{K}=$ Pencapaian indikator kemampuan berpikir kritis

Nilai persentase kemampuan berpikir kritis yang diperoleh dari perhitungan kemudian dikategorikan sesuai dengan tebel 3.6 berikut ini :

Tabel 3.6 Kategori Persentase Kemampuan

Berpikir Kritis Matematika

\begin{tabular}{|c|l|}
\hline Interpretasi (\%) & Kategori Penilaian \\
\hline $0<\mathrm{K} \leq 20$ & Sangat Rendah \\
\hline $20<\mathrm{K} \leq 40$ & Rendah \\
\hline
\end{tabular}

\begin{tabular}{|c|l|}
\hline Interpretasi (\%) & Kategori Penilaian \\
\hline $40<\mathrm{K} \leq 60$ & Sedang \\
\hline $60<\mathrm{K} \leq 80$ & Tinggi \\
\hline $80<\mathrm{K} \leq 100$ & Sangat Tinggi \\
\hline \multicolumn{2}{|c|}{ (Suwarma, 2009: 67) }
\end{tabular}

\section{Kriteria keberhasilan}

Peningkatan kemampuan berpikir kritis matematika peserta didik mencapai $80<\mathrm{K} \leq 100$ pada tes diakhir tiap siklus yang dikategorikan sangat tinggi.

\section{HASIL DAN PEMBAHASAN}

\section{A. Hasil Penelitian}

\section{Kemampuan Berpikir Kritis Matematika Pertemuan 1, 2, 3, dan 4}

Pelaksanaan pada pertemuan 1, 2, 3, 4 terlihat bahwa peserta didik masih susah untuk menyesuaikan diri dengan model pembelajaran probing prompting, seperti pada langkah pemberian pertanyaan awal peserta didik masih sedikit yang dapat menjawab, bahkan ada yang tidak menjawab ketika ditunjuk oleh guru. Pemberian pertanyaan awal oleh guru dapat meningkatkan kemampuan berpikir kritis peserta didik. Pertemuan 1 dan 2 indikator berpikir kritis yang ditingkatkan adalah menggeneralisasi, peserta didik dilatih untuk mengetahui sifat umum dari sisi kubus, balok, prisma, dan limas. Pertemuan 3 dan 4 dapat melatih kemampuan berpikir kritis dengan indikator menggeneralisasi dan indikator merumuskan masalah ke dalam model matematika, selain peserta didik dilatih untuk mengetahui sifat umum dari jaring-jaring kubus dan balok, peserta didik juga dilatih untuk menggambar jaring-jaring balok. Kemampuan berpikir kritis matematika peserta didik setiap pertemuan akan dinilai melalui hasil pengerjaan LKPD secara berkelompok. LKPD terdiri soalsoal yang telah disesuaikan dengan indikator kemampuan berpikir kritis matematika.

Pada langkah pemberian pertanyaan probing prompting yang terjadi adalah peserta didik masih susah untuk memahami pertanyaan-pertanyaan yang diberikan oleh guru, tampak bahwa masih ada 9 peserta didik yang tidak menjawab pertanyaan yang 
diberikan. Pertemuan 1 dan 3 pertanyaan probing prompting yang diberikan dapat meningkatkan indikator mengidentifikasi relevansi dan menggeneralisasi, pertemuan 2 dan 4 indikator yang ditingkatkan adalah sama dengan pertemuan sebelumnya hanya saja bertambah satu indikator yaitu mendeduksi menggunakan prinsip. Selanjutnya pada tahap pengerjaan LKPD secara berkelompok, hasil pengerjaan menunjukkan bahwa masih ada kelompok yang tidak mengerti terhadap soal tetapi tidak bertanya kepada guru, sehingga hasil pengerjaan LKPD siklus I hanya mampu memperoleh persentase kemampuan berpikir kritis 64\% dengan kategori tinggi, sebagai berikut :

Tabel 4.15 Hasil Kemampuan Berpikir

Kritis Matematika Peserta didik Siklus 1

\begin{tabular}{|c|c|c|c|}
\hline No. & $\begin{array}{c}\text { Pertemuan } \\
\text { ke- }\end{array}$ & $\begin{array}{c}\text { \% Berpikir } \\
\text { Kritis } \\
\text { Matematika } \\
\text { Peserta didik }\end{array}$ & $\begin{array}{c}\text { Kategori } \\
\text { Berpikir } \\
\text { Kritis } \\
\text { Matematika }\end{array}$ \\
\hline 1. & 1 & $52 \%$ & Sedang \\
\hline 2. & 2 & $64 \%$ & Tinggi \\
\hline 3. & 3 & $65 \%$ & Tinggi \\
\hline 4. & 4 & $74 \%$ & Tinggi \\
\hline \multicolumn{2}{|c|}{ Rata-Rata } & $64 \%$ & Tinggi \\
\hline
\end{tabular}

Berdasarkan tabel 4.15, rata-rata persentase hasil kemampuan berpikir kritis matematika peserta didik adalah $64 \%$ yang dikategorikan tinggi. Peserta didik dapat dikategorikan tinggi untuk kemampuan berpikir kritis matematikanya yaitu jika telah dapat menyelesaikan soal-soal sesuai dengan indikator berpikir kritis dengan baik.

\section{Kemampuan Berpikir Kritis Matematika Pertemuan 6, 7, 8, 9.}

Pertemuan $6,7,8,9$ peserta didik sudah mulai terbiasa dengan model probing prompting, sehingga peserta didik dapat mengikuti pembelajaran dengan baik, dan tentunya kemampuan berpikir kritisnya meningkat pula. Pemberian pertanyaan awal oleh guru untuk pertemuan $6,7,8,9$ disampaikan secara lisan di depan kelas dan menggunakan alat peraga, serta peserta didik juga antusias untuk menjawab pertanyaan. Setiap pertemuan, pertanyaan awal diberikan dan alat peraga yang digunakan disesuaikan dengan materi yang akan dipelajari. Tingkat pertanyaan pada pertemuan 6 dan 7 yaitu penerapan, sedangkan pada pertemuan 8 dan 9 mengalami penurunan yaitu pemahaman. Setiap pertanyaan awal bertujuan untuk meningkatkan kemampuan berpikir kritis peserta didik, hanya saja untuk setiap pertemuan indikator yang ditingkatkan akan berbeda. Hal seperti ini dapat meningkatkan kemampuan berpikir kritis peserta didik. Pertemuan 6 dan 7 indikator yang ditingkatkan melalui pertanyaan awal adalah menggeneralisasi, sedangkan pertemuan 8 dan 9 indikator yang ditingkatkan adalah mengidentifikasi relevansi. Pada langkah pemberian pertanyaan probing prompting yang terjadi pada siklus II ini adalah Tahap ini untuk pertemuan 6-9 selalu diawali dengan pertanyaan probing, hal ini menunjukkan bahwa peserta didik sudah dapat menjawab pertanyaan awal dengan benar. Indikator berpikir kritis yang ditingkatkan pada pertemuan 6 adalah indikator mendeduksi dengan menggunakan prinsip dan merumuskan masalah ke dalam model matematika. Pertemuan 7 indikator yang ditingkatkan adalah indikator mengidentifikasi relevansi, merumuskan masalah ke dalam model matematika dan mendeduksi dengan menggunakan prinsip. Indikator yang ditingkatkan pada pertemuan 8 yaitu indikator mendeduksi dan menggeneralisasi. Pertemuan 9 indikator yang ditingkatkan adalah menggeneralisasi, merumuskan masalah ke dalam model matematika.

Pertanyaan probing prompting pada pertemuan $6,7,8,9$ yang diberikan tentunya bertujuan untuk meningkatkan kemampuan berpikir kritis matematika peserta didik, hanya saja setiap pertemuan indikator yang ditingkatkan akan berbeda disesuaikan dengan pertanyaan yang diberikan. Namun masih ada peserta didik yang tidak menjawab pertanyaan dari guru, sehingga dia tidak dapat 
menyelesaikan LKPD dengan baik. Hasil pengerjaan LKPD juga semakin membaik, karena peserta didik telah terbiasa menyelesaikan LKPD sesuai dengan langkah penyelesaian kemampuan berpikir kritis yang memiliki 4 indikator yang berbeda, terlihat pada tabel 4.33 maka diperoleh rekapan untuk kemampuan berpikir kritis matematika peserta didik sebagai berikut :

Tabel 4.33 Hasil Kemampuan Berpikir Kritis Matematika Peserta didik Siklus II

\begin{tabular}{|c|c|c|c|}
\hline No. & $\begin{array}{l}\text { Pertemuan } \\
\text { ke- }\end{array}$ & $\begin{array}{l}\text { \% } \text { Berpikir } \\
\text { Kritis }\end{array}$ & $\begin{array}{l}\text { Kategori } \\
\text { Berpikir }\end{array}$ \\
\hline 1. & 6 & $88 \%$ & $\begin{array}{l}\text { Sangat } \\
\text { Tinggi }\end{array}$ \\
\hline 2. & 7 & $89 \%$ & $\begin{array}{l}\text { Sangat } \\
\text { Tinggi }\end{array}$ \\
\hline 3. & 8 & $87 \%$ & $\begin{array}{l}\text { Sangat } \\
\text { Tinggi }\end{array}$ \\
\hline 4. & 9 & $90 \%$ & $\begin{array}{l}\text { Sangat } \\
\text { Tinggi }\end{array}$ \\
\hline \multicolumn{2}{|c|}{ Rata-Rata } & $89 \%$ & $\begin{array}{c}\text { Sangat } \\
\text { Tinggi }\end{array}$ \\
\hline
\end{tabular}

Sumber : Lampiran 35

Tabel 4.33 menunjukkan bahwa rata-rata persentase hasil kemampuan berpikir kritis matematika peserta didik adalah $89 \%$ yang dikategorikan sangat tinggi. Terlihat bahwa setiap pertemuan pada siklus memiliki kategori kemampuan berpikir kritis sangat tinggi, namun dengan persentase kemampuan berpikir kritis yang selalu meningkat.

\section{Kemampuan Berpikir Kritis Matematika Pertemuan 11, 12, 13, 14}

Kemampuan berpikir kritis peserta didik menjadi semakin meningkat. Terlihat pada langkah pemberian pertanyaan pada siklus III ini telah berjalan dengan baik, terlihat dari keadaan kelas yang kondusif sehingga penyampaian lebih efektif. Setiap pertemuan, pertanyaan yang diberikan berbeda dan alat peraga yang digunakan juga berbeda. Tetapi, pada pertemuan 13 dan 14 alat peraga yang digunakan sama yaitu model limas dan balok. Indikator berpikir kritis yang digunakan juga berbeda setiap pertemuannya.
Pada langkah pemberian pertanyaan probing prompting akibat semakin banyak pertemuan, peserta didik semakin membaik terlihat dari pertemuan akhir di siklus III ini semua peserta didik menjawab pertanyaan dan terdapat 2 orang peserta didik yaitu RF dan NF yang menjawab tetapi masih ditunjuk oleh guru. Indikator berpikir kritis yang banyak dilatih dari pertanyaan adalah mengidentifikasi relevansi, mendeduksi, hanya sedikit pertanyaan menggeneralisasi,dan pertanyaan merumuskan masalah ke dalam model matematika.

Hasil pengerjaan LKPD memperlihatkan bahwa kategori berpikir kritis peserta didik adalah sangat tinggi, dengan rekapan sebagai berikut :

Tabel 4.51 Hasil Kemampuan Berpikir Kritis Matematika Peserta didik

\begin{tabular}{|c|c|c|c|}
\hline No. & $\begin{array}{c}\text { Pertemuan } \\
\text { ke- }\end{array}$ & $\begin{array}{c}\% \text { Berpikir } \\
\text { Kritis } \\
\text { Matematika } \\
\text { Peserta didik }\end{array}$ & $\begin{array}{c}\text { Kategori } \\
\text { Berpikir } \\
\text { Kritis } \\
\text { Matematika } \\
\end{array}$ \\
\hline 1. & 11 & $91,6 \%$ & Sangat Tinggi \\
\hline 2. & 12 & $95,8 \%$ & Sangat Tinggi \\
\hline 3. & 13 & $96,25 \%$ & Sangat Tinggi \\
\hline 4. & 14 & $97 \%$ & Sangat Tinggi \\
\hline \multicolumn{2}{|c|}{ Rata-Rata } & $95 \%$ & Sangat Tinggi \\
\hline
\end{tabular}

Berdasarkan tabel 4.51 bahwa rata-rata persentase hasil kemampuan berpikir kritis matematika peserta didik adalah $95 \%$ yang dikategorikan sangat tinggi. Setiap pertemuan pada pertemuan $11,12,13,14$ ini memiliki peningkatan, terlihat pada pertemuan 11 persentase kemampuan berpikir kritis 91,6\% dan pada pertemuan 14 menjadi $96,25 \%$. Hal tersebut memperlihatkan bahwa rata-rata persentase kemampuan berpikir kritis peserta didik hampi mencapai $100 \%$. Peserta didik semakin dapat menyelesaikan LKPD sesuai dengan indikator berpikir kritis. Sehingga pada pertemuan 11, 12, 13, 14 ini indikator keberhasilan tindakan telah tercapai sehingga tindakan dihentikan.

Disimpulkan bahwa rata-rata skor indikator berpikir kritis selalu meningkat, walaupun indikator menggeneralisasi dan 
mempertimbangkan hasil generalisasi pertemuan 1 sampai pertemuan 14 masih sama berada pada skor 3. Tiga indikator lainnya mengalami peningkatan sari 1 sampai 14 dan mencapai skor ideal yaitu 4, sehingga hal tersebut mempengaruhi kemampuan berpikir kritis. Berikut banyak peserta didik yang dikategorikan berpikir kritis tiap siklus :

Tabel 4.58 Rekapan Kategori Berpikir Kritis

\begin{tabular}{|c|c|c|c|c|c|}
\hline \multirow{2}{*}{ Pertemuan } & \multicolumn{5}{|c|}{ Kategori Berpikir Kritis } \\
\cline { 2 - 6 } & $\begin{array}{c}\text { Sangat } \\
\text { Rendah }\end{array}$ & Rendah & Sedang & Tinggi & $\begin{array}{c}\text { Sangat } \\
\text { Tinggi }\end{array}$ \\
\hline $1,2,3,4$ & $\begin{array}{c}0 \\
\text { peserta } \\
\text { didik }\end{array}$ & $\begin{array}{c}5 \\
\text { peserta } \\
\text { didik }\end{array}$ & $\begin{array}{c}14 \\
\text { peserta } \\
\text { didik }\end{array}$ & $\begin{array}{c}16 \\
\text { peserta } \\
\text { didik }\end{array}$ & $\begin{array}{c}1 \\
\text { peserta } \\
\text { didik }\end{array}$ \\
\hline $6,7,8,9$ & $\begin{array}{c}0 \\
\text { peserta } \\
\text { didik }\end{array}$ & $\begin{array}{c}0 \\
\text { peserta } \\
\text { didik }\end{array}$ & $\begin{array}{c}0 \\
\text { peserta } \\
\text { didik }\end{array}$ & $\begin{array}{c}\text { peserta } \\
\text { didik }\end{array}$ & $\begin{array}{c}19 \\
\text { peserta } \\
\text { didik }\end{array}$ \\
\hline \multirow{2}{*}{$11,12,13,14$} & $\begin{array}{c}0 \\
\text { peserta } \\
\text { didik }\end{array}$ & $\begin{array}{c}0 \\
\text { peserta } \\
\text { didik }\end{array}$ & $\begin{array}{c}0 \\
\text { peserta } \\
\text { didik }\end{array}$ & $\begin{array}{c}1 \\
\text { peserta } \\
\text { didik }\end{array}$ & $\begin{array}{c}\text { peserta } \\
\text { didik }\end{array}$ \\
\hline
\end{tabular}

Tabel 4.58 menunjukkan bahwa terdapat perbedaan disetiap siklusnya. Pertemuan 1,2,3,4 peserta didik berada pada 4 kategori yaitu kategori rendah, sedang, tinggi, dan sangat tinggi dan paling banyak peserta didik pada kategori tinggi. Peserta didik yang berpikir kritisnya dikategorikan rendah pada pertemuan 1,2,3,4 adalah AAP, DPH, RF, SM dan SPA, sedangkan peserta didik yang dikategorikan sangat tinggi adalah AAL . Sedangkan pada pertemuan 6,7,8,9 kemampuan berpikir kritis peserta didik berada pada 2 kategori yaitu kategori tinggi dan sangat tinggi, dengan jumlah peserta didik yang hampir sama. Pertemuan 11,12,13,14 kemampuan berpikir kritis peserta didik juga berada pada 2 kategori saja, dan 1 peserta didik saja yang masih dikategorikan tinggi, sedangkan 35 lainnya berada pada kategori sangat tinggi. Peserta didik yang dikategorikan tinggi tersebut adalah YNF.

Grafik Perbandingan Nilai Kemampuan Berpikir Kritis Matematika, sebagai berikut :

Peserta didik yang dikategorikan tinggi tersebut adalah YNF. Berikut perbandingan nilai kemampuan berpikir kritis tiap peserta didik :

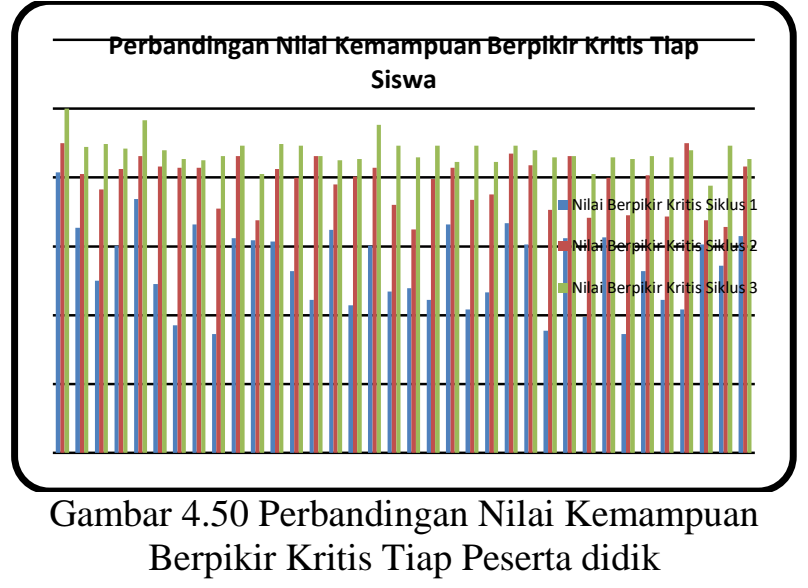

Gambar 4.50 menunjukkan bahwa hanya ada 1 peserta didik yang dapat mencapai skor berpikir kritis 100 yang diraih pada nilai kemampuan berpikir kritis pada pertemuan $11,12,13,14$. Pertemuan $1,2,3,4$ hanya ada 1 peserta didik saja yang berhasil mendapatkan nilai berpikir kritis lebih dari 80 yaitu AAL, yang memperoleh nilai lebih dari 60 dan kurang dari 80 ada sebanyak 12 orang peserta didik, lalu 18 orang peserta didik memperoleh nilai lebih dari 40 kurang dari 60, dan 5 orang peserta didik yang berada pada lebih dari 20 dan kurang dari 40. Peserta didik yang memperoleh skor lebih dari 80 dikategorikan memiliki kemampuan berpikir kritisnya sangat tinggi, 12 orang peserta didik dikategorikan tinggi, 18 orang peserta didik dikategorikan memiliki kemampuan berpikir kritisnya sedang ,dan 5 orang peserta didik yang masih dikategorikan rendah. Pertemuan 6,7,8,9 ada 18 peserta didik yang telah memperoleh skor diatas 80 , sehingga dikategorikan berpikir kritisnya sangat tinggi. 16 peserta didik masih memperoleh nilai diatas 60 dan kurang dari 80 dan tidak ada peserta didik yang dikategorikan sedang atau rendah. Tes akhir setelah pertemuan 11,12,13,14 mengalami peningkatan terdapat 35 peserta didik yang memperoleh nilai lebih dari 80 , dan hanya 1 peserta didik saja yaitu YNF yang masih memperoleh nilai 78.

Terdapat 1 peserta didik yaitu YS, nilai kemampuan berpikir kritisnya meningkat pada pertemuan 1,2,3,4 hingga pertemuan 9 , namun 
pada pertemuan akhir mangalami penurunan. Hal ini disebakan oleh kecerobohan dalam menyelesaiakan LKPD dan tes siklus, sehingga dapat mengurangi nilai berpikir kritis.

\section{B. PEMBAHASAN}

\section{Analisis Cara-Cara Meningkatkan Kemampuan Berpikir Kritis Matematika}

Kemampuan berpikir kritis matematika peserta didik setiap pertemuannya mengalami peningkatan, pada pertemuan 1,2,3,4 kemampuan berpikir kritis peserta didik dikategorikan sedang, pertemuan $6,7,8,9$ dikategorikan tinggi dan 11,12,13,14 dikategorikan sangat tinggi. Kemampuan berpikir kritis dinilai melalui pengerjaan LKPD dan tes akhir setelah 4 pertemuan. Pertemuan 1,2,3,4 persentase kemampuan berpikir kritis matematika peserta didik adalah 54\%. Rendahnya kemampuan berpikir kritis peserta didik pada pertemuan 1-4, dikarenakan peserta didik belum menyelesaikan sesuai langkah penyelesaian setiap indikator sehingga skor untuk setiap indikator belum ada yang mencapai skor ideal

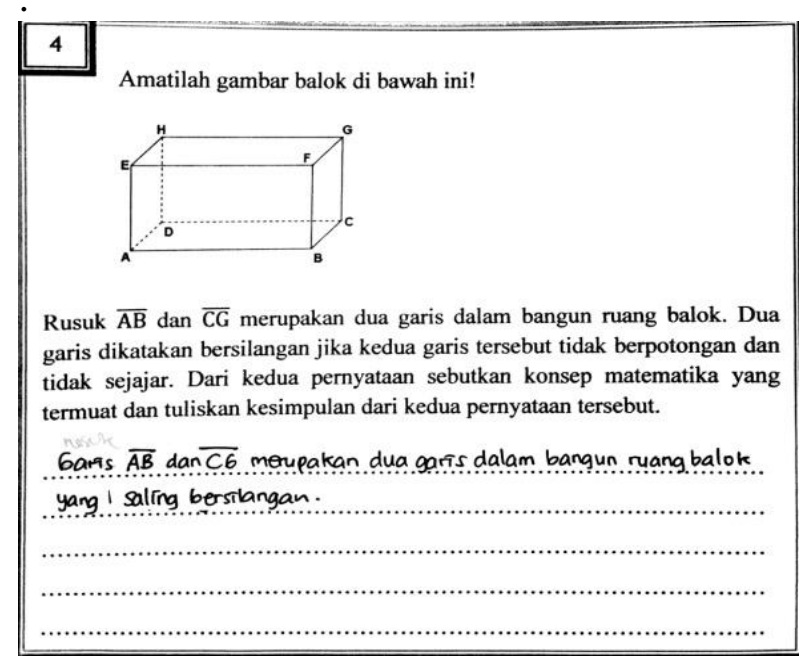

Gambar 4.69 Contoh penyelesaian LKPD indikator berpikir kritis mengidentifikasi relevansi

Hasil pengerjaan oleh peserta didik pada gambar 4.59 masih terdapat kesalahan. Langkah penyelesaian untuk indikator mengidentifikasi relevansi adalah mengidentifikasi data yang diketahui dan yang ditanyakan, namun peserta didik tidak melakukannya, langkah selanjutnya adalah mengidentifikasi syarat untuk penyelesaian masalah matematika maksudnya data apa saja yang dibutuhkan untuk membantu menyelesaikan permasalahan, kemudian memeriksa kesesuaian data yang diketahui dengan syarat untuk penyelesaian masalah matematika, terakhir mengidentifikasi data relevan atau tidak relevan disertai alasan. Hal tersebut masih dilakukan oleh banyak peserta didik.

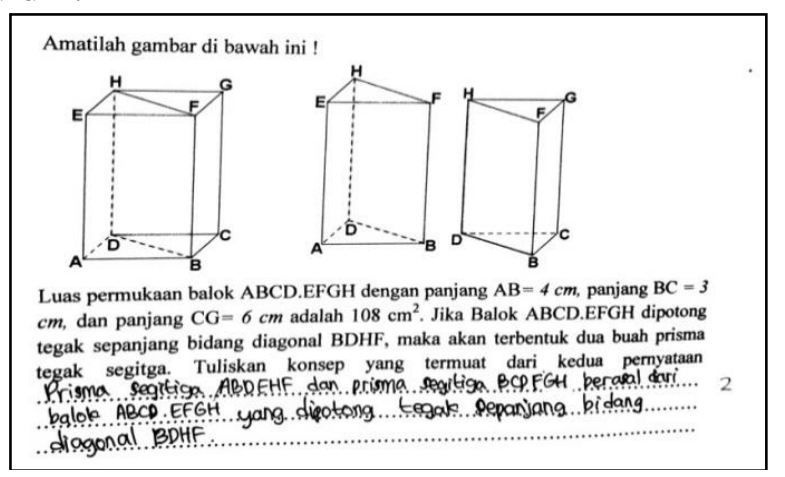

Gambar 4.74 Contoh Penyelesaian LKPD untuk indikator berpikir kritis mengidentifikasi relevansi

Hasil penyelesaian oleh peserta didik diatas tampak bahwa, peserta didik masih salah dalam membuat kesimpulan pada indikator berpikir kritis mengidentifikasi relevansi. Terlihat bahwa peserta didik hanya menjawab konsep yang termuat saja, yang termasuk dalam kriteria memeriksa kesesuain data yang diketahui dengan syarat untuk penyelesaian masalah matematika. Peserta didik masih salah dalam mebuat kesimpulan. Sehingga hal tersebut masih membuat peserta didik belum dapat memperoleh skor ideal pada indikator berpikir kritis ini, berbeda dengan siklus I bahwa peserta didik hanya membuat kesimpulan saja dan tidak membuat konsep yang termuat.

Hasil pengerjaan oleh peserta didik masih ada kesalahan. Persentase kemampuan berpikir kritis pada 4 pertemuan selanjutnya yaitu pertemuan $6,7,8,9$ meningkat menjadi $78 \%$ dikarenakan dilakukan perbaikan tindakan yang setelah pertemuan $6,7,8,9$ seperti, membimbing membuat langkah penyelesaian sesuai dengan indikator kemampuan berpikir

Nurmadhani, Agus, Della 
kritis sehingga peserta didik dapat memperoleh skor ideal, memberikan pertanyaan probingprompting dengan tingkat penerapan sehingga dapat melatih berpikir kritis peserta didik.

Pertanyaan probing prompting yang digunakan tidak hanya penerapan saja, tetapi juga diberikan dengan tingkat pemahaman, sehingga peserta didik tidak akan jenuh dengan pertanyaan yang diberikan.

Ada soal lainnya yang masih banyak kesalahan dilakukan oleh peserta didik yaitu pada soal no 1 tes akhir pertemuan $6,7,8,9$, yang dapat dilihat pada gambar 4.78.

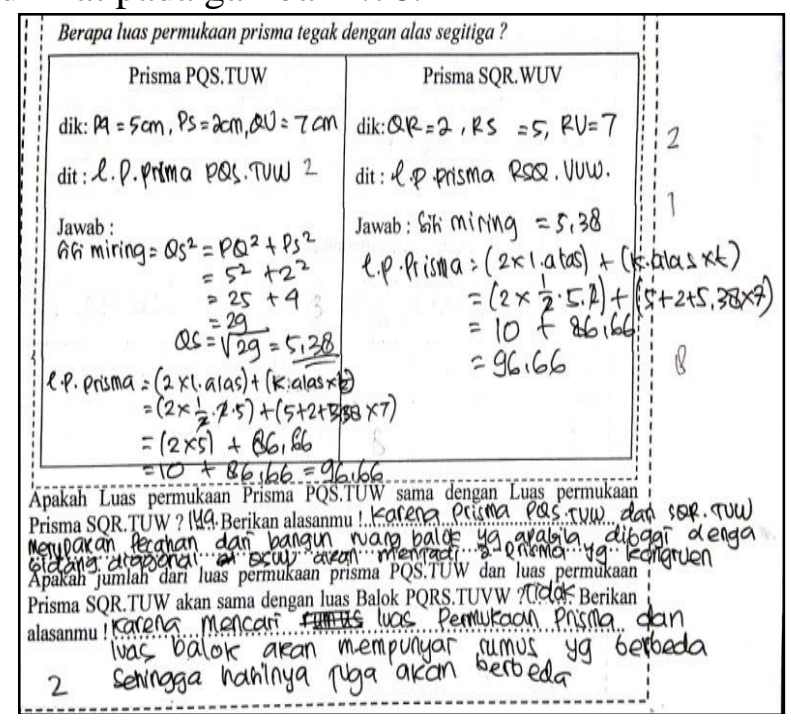

Gambar 4.78 Jawaban peserta didik kurang tepat pada soal no 1 tes siklus II

Gambar di atas menunjukkan bahwa peserta didik masih mengalami kesalahan pada indikator merumuskan masalah ke dalam model matematika dan indikator mengidentifikasi relevansi. Kesalahan yang dibuat oleh SKU pada indikator merumuskan masalah ke dalam model matematika adalah peserta didik tidak dapat membuat model dengan baik, seperti yang terlihat peserta didik tidak mensketsa segitiga yang gunanya untuk mendapatkan sisi miring dari segitiga dan juga peserta didik tidak menuliskan satuan dari luas permukaan prisma. Kesalahan pada indikator mengidentifikasi relevansi adalah peserta didik tidak bisa menuliskan kesamaan antara balok PQRS.TUVW dengan jumlah luas permukaan kedua prisma, sehingga SKU hanya memperoleh skor indikator masing-masing yaitu 3. Sedangkan peserta didik dalam mengerjakan soal tes lainnya pada tes akhir kedua tidak mengalami kesulitan.

Perbaikan setelah pertemuan 6,7,8,9 adalah mengingatkan peserta didik bahwa langkah penyelesaian dari soal yang diberikan mempengaruhi skor indikator berpikir kritis dan skor pengerjaan tes akhir siklus paling mempengaruhi persentase akhir kemampuan berpikir kritis peserta didik. Namun, masih ada saja peserta didik yang melakukan kesalahan dalam pengerjaan tes akhir setelah 4 pertemuan yaitu pertemuan $11,12,13,14$.

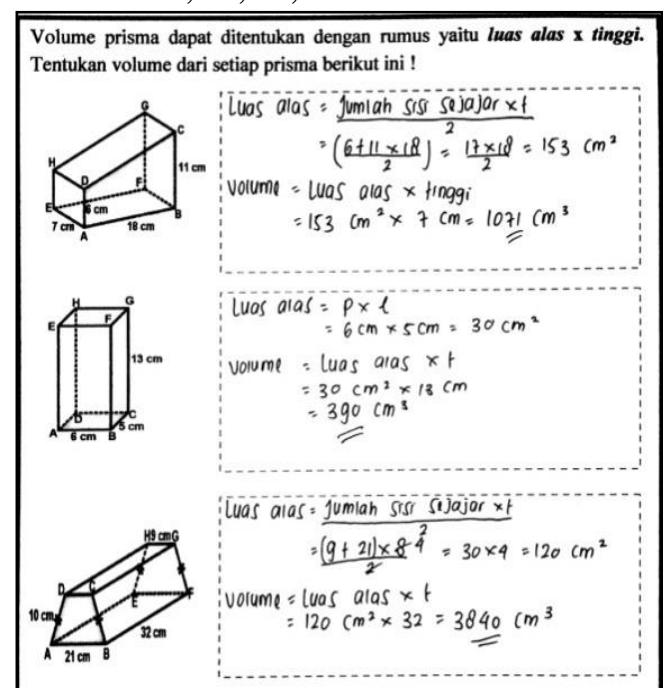

Gambar 4.79 Contoh Penyelesaian LKPD untuk indikator berpikir kritis mendeduksi dengan menggunakan prinsip

Gambar pengerjaan LKPD diatas dapat diselesaikan dengan benar oleh peserta didik, hanya saja pada prisma dengan alas trapesium sama kaki, peserta didik tidak membuat cara mendapatkan tinggi trapesium dan langsung menuliskan hasilnya saja. Hal seperti ini dibuat oleh 2 kelompok yaitu kelompok 7 dan 9 . Ketika ditanya guru "mengapa kalian tidak menuliskan cara mendapatkan tingginya"”, lalu peserta didik menjawab "kami menuliskannya ditempat lain bu". Akibat masalah itu, peserta didik tidak dapat mencapai skor ideal indikator mendeduksi dengan menggunakan prinsip, melainkan mereka hanya mencapai skor 3. 
Kemampuan berpkir kritis peserta didik pada tes akhir ketiga telah memperoleh persentase $87 \%$ dengan kategori sangat tinggi. Berdasarkan hasil tersebut, terlihat bahwa penerapan model pembelajaran probing prompting dapat meningkatkan kemampuan berpikir kritis matematika peserta didik.

Perbaikan tindakan yang terus menerus dilakukan dari pertemuan 1 sampai pertemuan 14 telah dapat dapat meningkatkan kemampuan berpikir kritis matematika peserta didik pertemuan 1 sampai 14. Terlihat dari persentase kemampuan berpikir kritis mengalami peningkatan rata-rata menjadi $87 \%$ dengan kategori sangat tinggi. sehingga telah memenuhi indikator keberhasilan yang ditetapkan. Berdasarkan persentase nilai akhir siklus I, II dan III tersebut menunjukkan proses pembelajaran dengan menerapkan model pembelajaran probing prompting dapat meningkatkan kemampuan berpikir kritis matematika peserta didik kelas VIII 1 SMP Negeri 04 Kota Bengkulu.

\section{PENUTUP}

\section{A. Kesimpulan}

Penerapan model pembelajaran Probing Prompting dapat meningkatkan kemampuan berpikir kritis matematika peserta didik dengan cara :

a. Memberikan bimbingan untuk menyelesaikan LKPD sesuai dengan langkah penyelesaian inidkator berpikir kritis.

b. Memberikan pertanyaan probing prompting dengan tingkat penerapan, sehingga peserta didik dapat terbiasa dengan berpikir kritis.

c. Menggunakan alat peraga dalam pemberian pertanyaan, sehingga peserta didik dapat lebih mudah mengasah kemampuan berpikir kritisnya.

d. Memberikan kesempatan kepada peserta didik untuk menyimpulkan hasil pembelajaran yang baru saja dibahas.
Berdasarkan penelitianyang telah dilakukan maka peneliti memberikan sedikit saran, sebagai berikut :

a. Penerapan model pembelajaran probing prompting diharapkan pada guru untuk tidak terlalu lama memberikan waktu tunggu kepada peserta didik.

b. Pertanyaan probing prompting yang diberikan hendaknya disesuaikan dengan indikator berpikir kritis yang ingin dicapai.

c. LKPD yang digunakan peserta didik hendaknya diberikan langkah-langkah penyelesaian setelah soal, agar peserta didik tidak membuat langkah penyelesaian yang sembarangan.

\section{DAFTAR PUSTAKA}

Arifah, Fita Nur.(2017).Penelitian Tindakan Kelas \& Karya Tulis Ilmiah untuk Guru. Yogyakarta: Araska.

Aqib,Zainal dkk.(2016).Penelitian Tindakan Kelas untuk Guru SD, SLB dan TK.Bandung: Remaja Rosdakarya.

Bassham, Gregory etc.(2011).Critical Thinking A Student's Introduction. New York:McGraw-Hill.

Emilia Tiara Putri.2016 .Penerapan Strategi Bertanya Probing Prompting Untuk Meningkatkan Hasil Belajar Peserta didik Kelas VIII 1 Semester 2 SMP Negeri 3 Kota Bengkulu Tahun Pelajaran 2015/2016". Skripsi tidak diterbitkan. Bengkulu: Program Sarjana Universitas Bengkulu.

Fisher, Alec.(2009).Berpikir Kritis Sebuah Pengantar.Jakarta: Erlangga.

Hendriana, Heris dan Soemarmo, Utari.(2017).Penilaian Pembelajaran Matematika.Bandung: PT Refika Aditama.

\section{B. Saran}


Huda, Miftahul.(2014).Model-Model Pengajaran dan Pembelajaran.Yogyakarta: Pustaka Pelajar.

Mayasari dkk .2014. "Penerapan Tekhnik Probing-Prompting Dalam Pembelajaran Matematika Peserta didik Kelas VIII MTSN Lubuk Buaya Padang. Jurnal Ilmiah Program studi Matematika.(Online), Vol 2. No.1

Normaya, Karim.Kemampuan Berpikir Kritis Peserta didik Dalam Pembelajaran Matematika Dengan Menggunakan Model Jucama Di Sekolah Menengah Pertama.Jurnal Pendidikan Matematika, (Online).Vol 3, No 1.

Santoso, Subyanto dkk .2014."Upaya Meningkatkan Keaktifan dan Prestasi Belajar Matematika Dengan Model Pembelajaran Probing-Prompting Pada
Peserta didik Kelas X Kulit A SMK Negeri 5 Yogyakarta".Jurnal Pendidikan Matematika.(Online), Vol 2, No 1

Shadiq, Fadjar.(2014).Strategi Pemodelan Pada Pemecahan Masalah Matematika.Yogyakarta: Graha Ilmu.

Shoimin, Aris.(2014).68 Model Pembelajaran Inovatif dalam Kurikulum 2013.Yogyakarta: Ar-Ruzz Media.

Suwarma, Dina Mayadiana.(2009).Suatu Alternatif Pembelajaran Kemampuan Berpikir Kritis Matematika.Jakarta: Cakrawala Maha Karya. 